\title{
DETERMINANTS OF YAM AGRIBUSINESS PARTICIPATION DECISIONS AMONG RURAL HOUSEHOLDS
}

\author{
Moradeyo Adebanjo OTITOJU * 1,2 (iD), Danjuma AHMADU ${ }^{2}$, Peter Ifeanyichukwu NWANDU ${ }^{3}$
}

\author{
Address: \\ ${ }^{1}$ Bioresources Development Centre, Ilesha, National Biotechnology Development Agency, Abuja, Nigeria \\ ${ }^{2}$ Department of Agricultural Economics, University of Abuja, Nigeria. \\ ${ }^{3}$ Department of Agricultural Economics and Extension, National Open University of Nigeria, Abuja, Nigeria. \\ * Correspondent author: maotitoju@gmail.com
}

\begin{abstract}
Research background: Participation decisions in yam agribusiness could be one of the measures to combat hunger, poverty and enhance the income of resource-poor rural households in yam-producing areas.

Purpose of the article: This study examined the determinants of yam agribusiness participation decisions and the factors that influence yam agribusiness export participation in Benue State, Nigeria.

Methods: The sampling technique used to select 385 respondents was multi-stage but 377 responses were used for the analysis in this study. This multinomial Logit and Probit models are employed to achieve the purpose of this study.

Findings \& Value: This study reveals that social capital, and literacy ratio influenced participation decision of rural households in input supply sector of yam agribusiness. Household size, age of household heads, literacy ratio and social capital influence the participation decisions in production sector of yam agribusiness. Age and gender of the households' heads and literacy ratio influenced participation decisions in distribution and transportation sector of yam agribusiness while Age of the household heads, access to credit, tenure security, social capital and literacy ratio influenced the marketing component of yam agribusiness in Nigeria. The Probit analysis shows that gender of the household heads, extension contact, dependency ratio and literacy ratio influenced the willingness to participate in yam export agribusiness. Policies on literacy improvement, participation in relevant cooperative societies, provision of extension services, and tenure security that propels rural households to participate in yam agribusiness should be enacted to enhance income and improve the wellbeing of Nigerians.
\end{abstract}

Key words: multinomial logit; participation decision; rural households; yam agribusiness JEL Codes: Q12; Q13

\section{INTRODUCTION}

West Africa has the largest capacity of about $92 \%$ of the production of 67.31 million of yam produced globally on 7.96 million hectatres of land (FAOSTAT, 2019). Even with the West Africa production, Nigeria, Ghana and Côte d'Ivoire produced about $66 \%$ of the world production. The benefits of yam as income earner and a source of food to versed majority of people cannot be overemphasized. Yam can be stored for a very long period of time because of its peculiar attribute of reduced physiological process that has the potential to cause deterioration unlike in other root and tubers in the tropics. It is very possible to deal with food insecurity largely by farming, processing, selling and distributing yams (Aighewi et al., 2014).

Yam is a major food crop that is widely grown in Nigeria. It is a first widely grown tuber crop in the agricultural economy, before cassava and others. The states with the highest levels of production (Taraba, Benue, and Niger) are not those with the highest yields (Nassarawa, Osun, Ekiti, Ondo, Imo). Benue state produces annual average of $60-70$ per count of the yam tonnes production in Nigeria
(Bergh et al., 2012). The farming of yam is largely still produce by smallholder farmers. But there is need to see how the households in the producing areas of Benue State are involved in yam agribusiness from the input supplies to the time the produce gets to the final consumers.

Agricultural Transformation Agenda (ATA, 2014) focuses more on agribusiness and farming that is directed towards marketing both at the local and international levels. In order to achieve these, there is need to deal with teething issues impeding the development of agri-food systems on a continuous basis. More importantly, there is need to encourage market participation of crops like root and tubers (Pingali et al., 2006).

Benue state produce the largest quantity and better quality of yams in Nigeria. In 2006, the National Bureau of Statistics (NBS, 2007) emphasized statistically that Benue State produced 13.017 million metric tonnes. Yams are consumed by humans, and for income generation and social, cultural, or religious events and festivals. Yam is produced, processed, distributed, marketed and considered important by rural households in Nigeria. The 
activities involved in yam agribusiness is carried out mainly in rural communities by the resident households.

A rural household participates in agriculture through the head or one of the members of the household to produce for the family and earn income. First, farm households vary both with respect to who constitutes a household (which family members) and with respect to what constitute a farm household (what level of production of land farmers, level of sales, share of household as farm household (FAOSTAT, 2019). Not all members of a household necessarily participate in agribusiness decisions. Because some decisions are jointly made, some are made by the heads of the households while some are made by the women in the households. This study emphasizes the identification of factors affecting decisions to participate in yam agribusiness and export by farm households in Benue State, Nigeria.

\section{LITERATURE REVIEW}

Despite their relative importance in rural food systems, very little yam is commercially marketed, exported and processed (Rohrbach, et al. 1990), this happened till very recent. A relatively small proportion of rural households participate in selling yams for those who want to buy, the quantity is often small (Barrett, 2008). Thus the main contribution of yams is towards farm household food security. The relative importance of yam in global food systems suggests the existence of substantial opportunities for their commercialization. It is about linking the farm households to the inputs (agrochemicals - pesticide, herbicide, seed yams, etc.) that they need on one side of the chain and exports of the commodity on the other side. Verter and Bečvářová (2015) posited that Nigeria produced more than $60 \%$ of the global yam production.

Subsidy was introduced on agricultural commodities to be exported in 2003. Recently, strategies were set in motion by the Nigerian Government to encourage larger investment in agricultural production, processing, distribution and marketing even to the extent of exportation. Yam is not left out among the crops of priorities. In the year 2017, the exportation started in Nigeria especially to the developed countries like the United States of America and the United Kingdom. This is encouraged by the Federal Government through favourable policies to agriculture in order to diversify from oil sector to non-oil sector. For increased and sustained production, processing, distribution and marketing system of yam, and participation decisions of farm households for export agribusiness has not been thoroughly defined.

Previous studies conducted in areas of export market that focused on market participation decision (e.g. Barret, 2008; Bobojonov et al., 2016; Enete and Igbokwe, 2009; Muriithi and Matz, 2014; Osmani and Hossain, 2015) did not focus on farm households' participation decisions in yam export agribusiness in Nigeria. Some of these studies already conducted used binary choice models (Logit and Probit) and also tobit model. Probit analysis was used by Bobojonov et al. (2016) to investigate the regressors of participation in export markets, and also a logistic regression model (i.e. Logit model) was used to examine main determinants of commercialization by Randela et al. (2008) within the transaction costs framework. In Sub-Saharan Africa, Heckman two-stage OLS regression was applied to examine factors of market participation in cereals among by smallholder farmers (Sizba et al., 2011). Also, Tobit model was used by Enete and Igbokwe (2009) to examine decisions to participate in cassava market by households in Africa, but none of these studies used a polytomous choice model to examine the market participation decisions. Kyaw, Ahn and Lee (2018) used Heckman two-stage selection model to examine the factors that affect market participation by small-scale rice farmers. Double hurdle model was used by Achandi and Mujawamariya (2016) to examine the market participation among smallholder rice farmers.

The objectives of the study were to: examine the determinants of yam agribusiness participation decisions, and investigate the factors influencing yam agribusiness export participation in Benue State, Nigeria. These objectives were carried out using polytomous and binary choice models (multinomial Logit and Probit models), respectively. This was actually done to know the relevant policy variables that could necessitate vibrant yam agribusiness in Nigeria.

\section{DATA AND METHODS}

\section{Data source and sampling procedure}

The sampling approach used to conduct a survey to select household respondents was multi-stage method. The major yam-producing areas of Benue State, Nigeria were purposively selected for the study, that is, the Northern and Eastern agricultural zones consisting of 14 local government areas, this marks the stage one. Secondly, two local government areas were randomly sampled in each zone, making four local government areas all together. Thirdly, from each local government, two districts were selected, making eight districts. Benue State Agricultural and Rural Development Authority (BNARDA) office at the zonal level provided the lists of the yam farmers and marketers. This served as the sampling frame. The unit of analysis is farm households. The Equation (1) provided by Anderson et al. (2007) was adopted to select the households.

$n=\frac{P q Z^{2}}{E^{2}}$

\section{Where:}

$n=$ sample size $P=$ proportion of the population of the rural households; $q=1-P ; Z=$ confidence level $(\alpha=$ 1.96); E acceptable error (0.05). This formula resulted to sampling 385 respondents. But 377 responses were used for the analysis and discussion after removing the outliers and those questionnaires of incomplete response.

\section{Empirical Model: The Multinomial Logit Model}

The application of multinomial Logit model in this analysis is necessitated to estimate the explanatory variables (i.e. determinants) affecting the decisions to participate in the operations of yam agribusiness because of the multivariate nature of the dependent variable. This 
determines the odds of a household being in one of the four categories of participation decisions by input supplies, production, processing-storage-distribution or marketing. The dependent variable (participation decision) is quantified numerically as follows: no participation equals 0,1 for input supplies, 2 for production, 3 for processing-transportation-distribution and 4 for marketing. This categorization is never done following any specific order as in the case of ordered Logit model. Additionally, the participation in the operations by the households was possible but the respondents was categorized by the major operation.

To address the issue of choice that is more than two response outcomes multinomial Logit model was one of the polytomous models to use (Gujarati, Porter and Gunasekar, 2012). To effectively apply this model, one of the participation decisions was set to be the reference category (i.e. base outcome), which is assumed to be zero $(0)$. In other words, we compare the case of nonparticipation (0) in yam agribusiness with other possible operations (1, 2, 3 and 4). The Model is explicitly stated as Equation (2).

$Y_{i}^{*}=\alpha+\beta_{1} X_{1}+\beta_{2} X_{2}+\beta_{3} X_{3}+\beta_{4} X_{4}+\beta_{5} X_{5}+$

$\beta_{6} X_{6}+\beta_{7} X_{7}+\beta_{8} X_{8}+\beta_{9} X_{9}+\beta_{10} X_{10}+\beta_{11} X_{11}$

The description and measurement of the dependent and the independent or explanatory variables, referred to as regressors, for the multinomial Logit analysis are as stated in Table 1.

\section{Empirical Model: The Probit Analysis}

For the identification of the factors that influence the decisions of farm household participating in yam export agribusiness, Probit model was applied. This is specified as Equation (3).

$\pi_{i}=\Phi\left(\eta_{i}\right)=\Phi\left(\alpha+\beta_{i} X_{i 1}+\beta_{2} X_{i 2}+\cdots+\beta_{k} X_{i k}\right.$

$\pi_{i}=\Phi\left(X_{i}^{t}\right)$

Where:

$\Phi($.$) is distribution function for the Standard Normal$ Random Variable; $\alpha$ and $\beta_{i}$ are parameters to be estimated; $\pi_{i}$ conditional probability; $\beta_{i}$ coefficients of the independent variables i.e. regressors); $X_{i}$ the explanatory variables, and $\varepsilon_{i}$ error term. What differentiate Probit model from Logit model is the normal distribution of errors as stated (Equation 5). Logistic regression model assumes logistic distribution of errors.

$\Phi-1_{\left(Y_{t}\right)}=\sum_{k=o}^{k-n} \beta_{k} X_{i k}^{2} \varepsilon_{i}$

This is implicitly stated as Equation (6).

$Y_{t}^{*}=\beta_{i} X+\varepsilon_{i}$

Where:

$Y_{i}^{*}$ the binary dependent variable of willingness-toparticipate in yam export agribusiness (if willing to participate $=1,0$ otherwise); $X_{i}$ are the explanatory or independent variables; $\beta_{i}$ are parameters of the regressors (independent variables), and $\varepsilon_{i}$ error term.

Logistic regression can be explicitly stated as Equation (7).

$Y_{i}^{*}=\alpha+\beta_{1} X_{1}+\beta_{2} X_{2}+\beta_{3} X_{3}+\beta_{4} X_{4}+\beta_{5} X_{5}+$

$\beta_{6} X_{6}+\beta_{7} X_{7}+\beta_{8} X_{8}+\beta_{9} X_{9}+\beta_{10} X_{10}+\varepsilon_{i}$

The dependent and the independent or explanatory variables considered as determinants of decisions to participate in yam export agribusiness by farm households in the Probit regression analysis are as shown in Table 2:

\section{RESULT AND DISCUSSION}

\section{Factors that influence Yam Agribusiness Participation Decisions among Rural Households in Benue State, Nigeria}

Non-participation in yam agribusiness is the comparison category. The analytical outcomes of the multinomial Logit model are presented in Table 3. The results presented comprise the coefficients and the standard errors of the regressors are also presented.

The significant strength of the explanation of the multinomial model rests in the likelihood ratio statistics $\left(\chi^{2}\right)(\mathrm{p}<0.0000)$. The effect of the regressors' coefficients provide direction of the dependent variable in comparison with the base outcome. Marginal effects of the regressors are also taken into consideration. This is necessary because it helps to avoid a misleading results if only the explanation on the coefficients are used. These marginal effects are reported in Table 4.

Household size: The relationship that exists between household size and the probability of participating in production/farming of yam tubers tends to make both of them to move in the same direction as seen in Table 4 . This shows that rural households with more people tend to produce yam more than households with few people.

Age of household head: The likelihood of participation of farm households in yam production/farming, transportation-distribution and marketing is related to the age of the head of the households in positive manner. It shows that as the rural households' heads get older they tend to decide to participate not only in the production, transportation and marketing components of yam agribusiness in Nigeria. Geoffrey et al. (2013) posited that age is an important factor in market participation as revealed in pineapple market in Kenya.

Gender of the household head: The probability of participation in transportation-distribution of yam is positively related to gender of the respondents.

Access to Credit: The probability of participation in marketing of yam tubers and access to credit are significantly related among rural households. This result is in disagreement with microeconomic theory on access to credit. This is may be due to fungibility of credit. 
Table 1: Description, measurement and expected signs of the dependent and the independent variables (regressors) in the multinomial Logit analysis

\begin{tabular}{|c|c|c|c|c|c|}
\hline Variable Names & Variable Description and Measurement & Unit of Measurement & Parameters & $\begin{array}{l}\text { Variable } \\
\text { Notations }\end{array}$ & $\begin{array}{l}\text { Expected sign (a } \\
\text { priori expectation) }\end{array}$ \\
\hline $\begin{array}{l}\text { Yam agribusiness } \\
\text { operations }\end{array}$ & $\begin{array}{l}\text { This stands for multivariate choices of five (5) possible values; } 0 \text { for non- } \\
\text { participation in yam agribusiness, } 1 \text { for input supplies, } 2 \text { for } \\
\text { production/farming, } 3 \text { for processing-transportation-distribution and } 4 \text { for } \\
\text { marketing. }\end{array}$ & Discreet choice & - & $Y_{i}^{*}$ & \\
\hline Household size & Number of persons in the household & Number of persons & $\beta_{1}$ & $\mathrm{X}_{1}$ & + \\
\hline $\begin{array}{l}\text { Age of the } \\
\text { household head }\end{array}$ & The number of years that the household head has been living & Years & $\beta_{2}$ & $\mathrm{X}_{2}$ & \pm \\
\hline $\begin{array}{l}\text { Years of education } \\
\text { of household head }\end{array}$ & This is highest education level the respondent possess. & Years of schooling & $\beta_{3}$ & $\mathrm{X}_{3}$ & + \\
\hline $\begin{array}{l}\text { Sex of the } \\
\text { household head }\end{array}$ & The sex category of the household head & $\begin{array}{l}\text { Dummy (measured as } 1 \text { if male, } \\
0 \text { otherwise) }\end{array}$ & $\beta_{4}$ & $\mathrm{X}_{4}$ & \pm \\
\hline Extension contact & The number of extension contact/visit in the year & Number & $\beta_{5}$ & $\mathrm{X}_{5}$ & + \\
\hline Access to credit & Access to credit & $\begin{array}{l}\text { Dummy (Measured as } 1 \text { if the } \\
\text { respondent has access to credit, } 0 \\
\text { otherwise) }\end{array}$ & $\beta_{6}$ & $\mathrm{X}_{6}$ & + \\
\hline Tenure security & The ownership of land used in farming yam & $\begin{array}{l}\text { Dummy ( } 1 \text { if land used for } \\
\text { farming yam is owned by the } \\
\text { respondents, } 0 \text { otherwise }\end{array}$ & $\beta_{7}$ & $\mathrm{X}_{7}$ & + \\
\hline Funded project & The participation in funded agricultural project & $\begin{array}{l}\text { Dummy ( } 1 \text { if participated in } \\
\text { funded agricultural project, } 0 \\
\text { otherwise); }\end{array}$ & $\beta_{8}$ & $\mathrm{X}_{8}$ & + \\
\hline Social Capital & Memberships in cooperative societies and farmers' associations & $\begin{array}{l}\text { Dummy ( } 1 \text { if belong to } \\
\text { cooperative societies and } \\
\text { farmers' associations, } 0 \\
\text { otherwise); }\end{array}$ & $\beta_{9}$ & $\mathrm{X}_{9}$ & + \\
\hline Dependency ratio & $\begin{array}{l}\text { The ratio of the number of people that are depending on the household } \\
\text { head living under the same roof divided by the total number of people in } \\
\text { the household in the cropping year }\end{array}$ & Number in ratio & $\beta_{10}$ & $\mathrm{X}_{10}$ & + \\
\hline Literacy ratio & $\begin{array}{l}\text { The ratio of the number of people that can read and write to total number } \\
\text { of people under the same roof }\end{array}$ & Number in ratio & $\beta_{11}$ & $\mathrm{X}_{11}$ & + \\
\hline Constant & - & & $\beta_{0}$ & - & \\
\hline
\end{tabular}


Table 2: Description, Measurement and Expected Signs of the Dependent and the Independent Variables (Regressors) in the Probit Regression Analysis

\begin{tabular}{|c|c|c|c|c|c|}
\hline Variable Names & Variable Description and Measurement & Unit of Measurement & Parameters & $\begin{array}{l}\text { Variable } \\
\text { Notations }\end{array}$ & $\begin{array}{l}\text { Expected sign (a priori } \\
\text { expectation) }\end{array}$ \\
\hline $\begin{array}{l}\text { Willingness-to- } \\
\text { participate in yam export } \\
\text { agribusiness }\end{array}$ & $\begin{array}{l}\text { Binary dependent variable, measured as a dummy, } 1 \text { if } \\
\text { willing-to-participate, } 0 \text { otherwise. }\end{array}$ & Dummy & - & $Y_{i}^{*}$ & \\
\hline Household size & Number of persons in the household & Number of persons & $\beta_{1}$ & $\mathrm{X}_{1}$ & + \\
\hline $\begin{array}{l}\text { Age of the household } \\
\text { head }\end{array}$ & $\begin{array}{l}\text { The number of years that the household head has been } \\
\text { living }\end{array}$ & Years & $\beta_{2}$ & $\mathrm{X}_{2}$ & \pm \\
\hline $\begin{array}{l}\text { Years of education of } \\
\text { household head }\end{array}$ & This is highest education level the respondent possess. & Years of schooling & $\beta_{3}$ & $\mathrm{X}_{3}$ & + \\
\hline $\begin{array}{l}\text { Sex of the household } \\
\text { head }\end{array}$ & The sex category of the household head & $\begin{array}{l}\text { Dummy (measured as } 1 \text { if } \\
\text { male, } 0 \text { otherwise) }\end{array}$ & $\beta_{4}$ & $\mathrm{X}_{4}$ & \pm \\
\hline Extension contact & The number of extension contact/visit in the year & Number & $\beta_{5}$ & $\mathrm{X}_{5}$ & + \\
\hline Farm size & $\begin{array}{l}\text { The size of land cultivated to yam during the cropping } \\
\text { year }\end{array}$ & Hectares & $\beta_{6}$ & $\mathrm{X}_{6}$ & \pm \\
\hline Tenure security & The ownership of land used in farming yam & $\begin{array}{l}\text { Dummy ( } 1 \text { if land used for } \\
\text { farming yam is owned by } \\
\text { the respondents, } 0 \text { otherwise }\end{array}$ & $\beta_{7}$ & $\mathrm{X}_{7}$ & + \\
\hline Social Capital & $\begin{array}{l}\text { Absolute frequency of memberships in the } \\
\text { cooperative societies and farmers' association }\end{array}$ & $\begin{array}{l}\text { A count of associations and } \\
\text { cooperative societies the } \\
\text { respondent belongs to } \\
\text { during the cropping year. }\end{array}$ & $\beta_{8}$ & $\mathrm{X}_{8}$ & + \\
\hline Dependency ratio & $\begin{array}{l}\text { The ratio of the number of people that are depending } \\
\text { on the household head living under the same roof } \\
\text { divided by the total number of people in the } \\
\text { household in the cropping year }\end{array}$ & Number in ratio & $\beta_{9}$ & $X_{9}$ & + \\
\hline Literacy ratio & $\begin{array}{l}\text { The ratio of the number of people that can read and } \\
\text { write to total number of people under the same roof }\end{array}$ & Number in ratio & $\beta_{10}$ & $\mathrm{X}_{10}$ & + \\
\hline Constant & - & & $\beta_{0}$ & - & \\
\hline
\end{tabular}


Tenure security: The likelihood of participating in marketing of yam tubers and tenure security move in the same direction. The implication is that land owners participate more the marketing component of yam agribusiness than their counterparts. Tenants can use lands as collateral, so land ownership influences the rural households' participation decisions in yam agribusiness. This is in agreement with Oparinde and Daramola (2014) which posited that land tenure affects participation of the respondents in the market participation. Otitoju (2013) and Enete, Otitoju and Ihemezie (2015) posited the agreement between tenure security and decisions.

Social Capital: Table 4 shows that membership in social, civil and farmers' cooperative has negative and significant relationship with the three components of yam agribusiness (i.e. input supply/seller, production/farmers, and marketing in the study area. When people are members of a group, there are benefits attributed (Key and Runsten, 1999). When people belong to the same group, they pull their resources to solve their problems collectively (Matungul et al., 2001). Social capital had negative sign in this study. This looks very strange but it could be due to the formation of Association of Yam Farmers, Processors and marketers, Nigeria newly with the primary aim of promoting yam value chain businesses throughout the country which is different from membership of general cooperative without the primary function of this nature. Markelova et al., 2009 and Poulton et al., 2010 in their works posited that this finding may mean that when members get subsumed in social groups this may limit their activities in ensuring profitable marketing.

Literacy Ratio: Literacy ratio is the ratio of the number of people that have the ability to read and write to the whole number of people living together under a roof. The results of this study show that literacy ratio and the likelihood of participation decisions of all the components of yam agribusiness among the rural households in Benue State, Nigeria. This relationship tends to make them to move together.

Table 3: The coefficients of the regressors that influence the rural households' participation decisions in yam agribusiness in Benue State, Nigeria

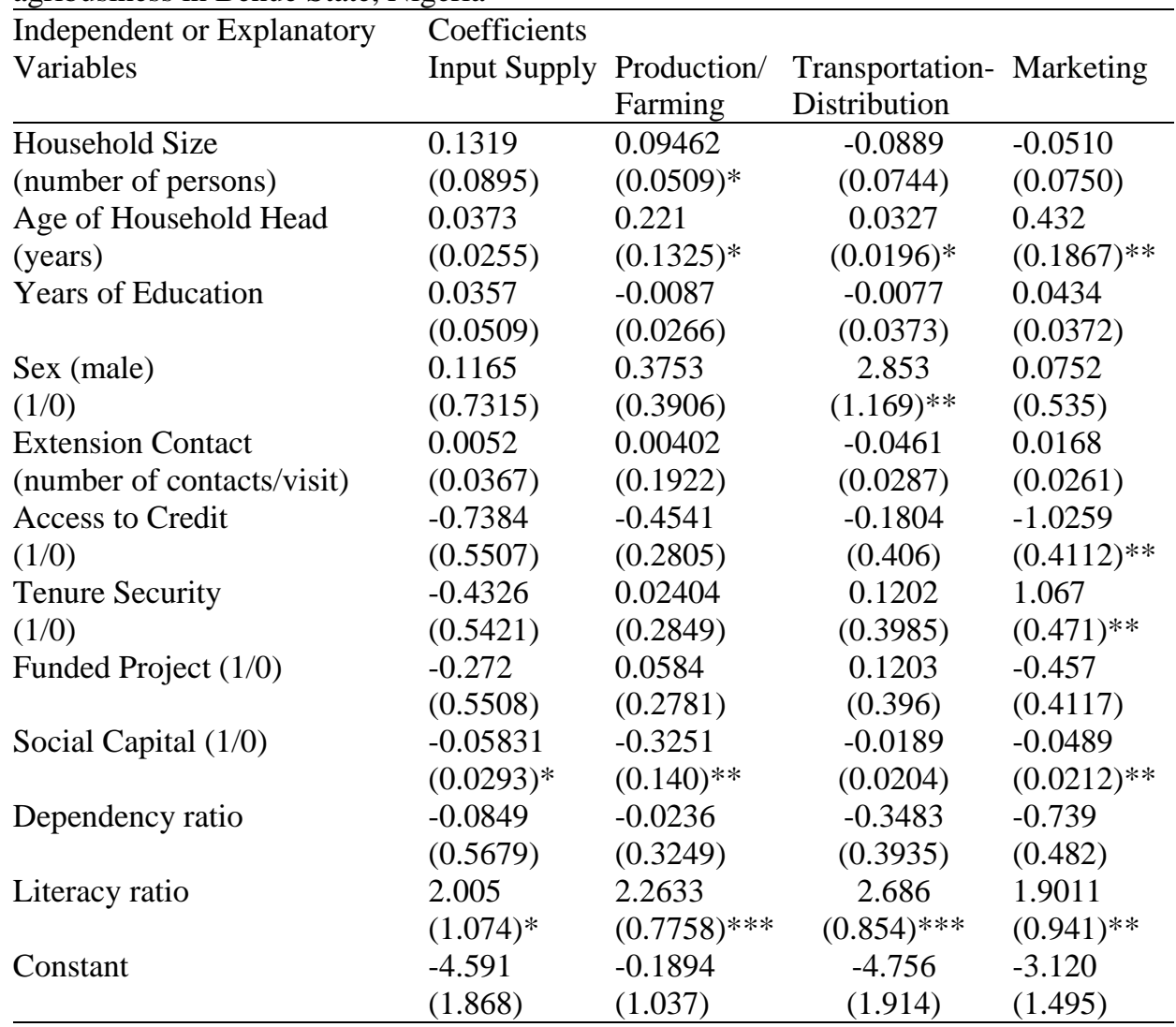

Numbers of observation $=377$

LR chi2 (44) $=92.95$

Log likelihood $=-474.45$

Prob $>$ chi $2=0.0000$

Psuedo $\mathrm{R}^{2}=0.0892$

Note: The reference category is non-participation in yam agribusiness. Standard errors in parenthesis;

$* * *$ denotes $\mathrm{P} \leq 0.01, * *$ denotes $0.01<\mathrm{P} \leq 0.05$, while $*$ denotes $0.05<\mathrm{P} \leq 0.10$

Source: Computed from field survey, 2018. 
Table 4: Marginal effects of the multinomial Logit (mnl) analysis of factors that influence the rural household participation decisions in yam agribusiness in Benue State, Nigeria

\begin{tabular}{|c|c|c|c|c|c|}
\hline $\begin{array}{l}\text { Explanatory } \\
\text { Variables }\end{array}$ & $\begin{array}{l}\text { dy/dx } \\
\text { Non-participation } \\
\text { in yam } \\
\text { agribusiness }\end{array}$ & $\begin{array}{l}\text { Input } \\
\text { Supply }\end{array}$ & Production/Farming & Transportation & Marketing \\
\hline Household Size & 0.0047 & 0.0273 & -0.0099 & -0.0123 & -0.00973 \\
\hline (number of persons) & $(0.0025)^{*}$ & $(0.0101)^{* *}$ & $(0.0096)$ & $(0.0064035)^{*}$ & $(0.0071)$ \\
\hline Age of Household Head & 0.000847 & 0.00075 & -0.00522 & 0.001171 & 0.00245 \\
\hline (years) & $(0.00114)$ & $(0.0026)$ & $(0.00214)^{* *}$ & $(0.00152)$ & $(0.00165)$ \\
\hline Years of Education & $\begin{array}{c}0.00173 \\
(0.0254)\end{array}$ & $\begin{array}{l}-0.00500 \\
(0.00515)\end{array}$ & $\begin{array}{c}-0.000380 \\
(0.00462)\end{array}$ & $\begin{array}{l}-0.000887 \\
(0.00302)\end{array}$ & $\begin{array}{c}0.00453 \\
(0.00279)\end{array}$ \\
\hline Sex (male)* & -0.0120 & 0.0164 & -0.0957 & 0.122 & -0.0309 \\
\hline$(1 / 0)$ & $(0.0402)$ & $(0.0777)$ & $(0.7325)$ & $(0.0250) * * *$ & $(0.0475)$ \\
\hline Extension Contact & 0.00028 & 0.00217 & 0.00010 & -.00441 & -0.0309 \\
\hline (number of contacts/visits) & $(0.0186)$ & $(0.0378)$ & $(0.00304)$ & $(0.00188)^{* *}$ & $(0.0475)$ \\
\hline Access to Credit* & 0.0141 & -0.0499 & 0.09015 & 0.0164 & 0.00186 \\
\hline$(1 / 0)$ & $(0.0257)$ & $(0.0565)$ & $(0.0504)^{*}$ & $(0.0307)$ & $(0.00242)^{* *}$ \\
\hline Tenure Security* & -0.0286 & -0.0347 & -0.0240 & -0.00730 & 0.0947 \\
\hline$(1 / 0)$ & $(0.0291)$ & $(0.0568)$ & $(0.0492)$ & $(0.0299)$ & $(0.0332) * * *$ \\
\hline \multirow[t]{2}{*}{ Funded Project $(1 / 0)^{*}$} & -0.0118 & 0.0438 & 0.00759 & 0.00406 & -0.0436 \\
\hline & $(0.0238)$ & $(0.0558)$ & $(0.0492)$ & $(0.0304)$ & $(0.0322)$ \\
\hline \multirow[t]{2}{*}{ Social Capital $(1 / 0)^{*}$} & -0.00164 & -0.00318 & 0.0066 & 0.00068 & -0.00247 \\
\hline & $(0.00128)$ & $(0.00294)$ & $(0.00247)^{* * *}$ & $(0.0018)$ & $(0.0018)$ \\
\hline \multirow[t]{2}{*}{ Dependency ratio } & $(0.00226$ & 0.0520 & 0.0328 & -0.0211 & -0.0659 \\
\hline & $(0.0206)$ & $(0.0537)$ & $(0.515)$ & $(0.0277)$ & $(0.0427)$ \\
\hline \multirow[t]{2}{*}{ Literacy ratio } & 0.0165 & 0.2874 & -0.425 & 0.0972 & 0.0241 \\
\hline & $(0.03086)$ & $(0.1385)^{* *}$ & $(0.192) * *$ & $(0.0471)^{* *}$ & $(0.0511)$ \\
\hline
\end{tabular}

Note: $* \mathrm{dy} / \mathrm{dx}$ is for discreet change of the variable that are binary from 0 to 1 ; Standard errors in parenthesis

Table 5: Probit Analysis of Determinants of the Rural Households' Willingness-to-Participate in Yam Export Agribusiness in Nigeria

\begin{tabular}{lrrrr}
\hline Explanatory Variables & Coefficients & Standard Error & Z-Value & $\mathrm{P}>|\mathrm{Z}|$ \\
\hline Household Size (number) & 0.01616 & 0.0275 & 0.59 & 0.557 \\
Age of Household Head (years) & -0.00316 & 0.00676 & -0.47 & 0.640 \\
Years of Education & 0.00722 & 0.0131 & 0.55 & 0.580 \\
Sex (male) (1/0) & 0.3308 & 0.198 & $1.67^{*}$ & 0.094 \\
Extension Contact (number) & 0.0154 & 0.00934 & $1.65^{*}$ & 0.098 \\
Farm size (Hectares) & -0.05099 & 0.0349 & -1.46 & 0.145 \\
Tenure Security (1/0) & -0.0883 & 0.1460 & -0.60 & 0.545 \\
Social Capital (absolute frequency & -0.00605 & 0.00729 & -0.83 & 0.407 \\
of memberships) & & & & \\
Dependency ratio & 0.748 & 0.227 & $3.29 * * *$ & 0.001 \\
Literacy ratio & -0.675 & 0.328 & $-2.06 * *$ & 0.040 \\
Constant & 0.161 & 0.532 & 0.30 & 0.762 \\
\hline Numbers & & & &
\end{tabular}

Numbers of observation $=377$

Wald chi2 $(10)=25.32$

Log pseudo likelihood $=-234.159$

Prob $>$ chi $2=0.0048$

Psuedo $\mathrm{R}^{2}=0.0830$

Note: *** denotes $\mathrm{P} \leq 0.01$, ** denotes $0.01<\mathrm{P} \leq 0.05$, while * denotes $0.05<\mathrm{P} \leq 0.10$

Source: Computed from field survey, 2018.

Determinants of Participation Decisions in Yam Export Agribusiness by Rural Households in Benue State, Nigeria

Sex, extension contact, dependency ratio, and literacy ratio are the determinants of participation in yam export agribusiness as revealed by the results of the Probit model analysis. The estimated Probit regression analysis shows a high level of significance as shown by likelihood ratio statistics $\left(\chi^{2}\right)$ at $95 \%$ confidence level. This value suggests the magnitude of the strength to explain the Probit regression model.

Sex: Sex and willingness-to-participate in yam export agribusiness are positive and statistically related. Here, it means that male rural households' heads are willing to participate more in yam export agribusiness than their female counterpart. Schipmann and Qaim (2011); 
Geoffrey et al. (2013) attested to this result of positive relation between gender and market participation.

Extension contact: Extension contact and the willingness-to-participate in yam export agribusiness in Nigeria are positively. This means that the more the agricultural extension contacts the more the rural households will be willing to participate in yam export agribusiness. This shows that extension activities have to be geared towards yam agribusiness to help the government in the diversification of Nigeria economy from oil-dependence to agribusiness-led economy. Bobojonov et al. (2016) reported that age is a critical determinant of export market participation in Armenia but cooperative membership and extension contact are factors that influenced participation of farm households in export markets in Uzbekistan.

Dependency ratio: It is clear in Table 5, that dependency ratio has significant relationship with households' willingness-to-participate in yam export agribusiness. This shows that the more the number of people that are dependent on the households heads the more the households is looking for way to cater for their wellbeing.

Literacy ratio: The negative relationship between literacy ratio and household heads' willingness-toparticipate in yam agribusiness is surprising but it shows that the number of literate people in a household is not a determinant of participation in yam agribusiness. This is so because many literate people do not stay in the rural areas.

\section{CONCLUSIONS AND RECOMMENDATIONS}

The analysis of this study demonstrates that there are determinants that can enhance the participation decisions in yam agribusiness and also that drive the willingness-toparticipate in yam export agribusiness (Selling to the companies that are directly involved in yam export, i.e. off takers) among farm households. Participation decisions in yam agribusiness could be one of the measures to combat hunger, poverty and enhance the income of millions of resource-poor rural households. This multinomial Logit estimation reveals that social capital, and literacy ratio influenced participation decision of rural households in input supply sector of yam agribusiness. Household size, age of households; heads, literacy ratio and social capital influence the participation decisions in production sector of yam agribusiness. Age and gender of the households' heads and literacy ratio influenced participation decisions in distribution-transportation sector of yam agribusiness while Age of the household heads, access to credit, tenure security, social capital and literacy ratio influenced the marketing component of yam agribusiness in Nigeria. The Probit analysis shows that gender of the household heads, extension contact, dependency ratio and literacy ratio influenced the willingness-to-participate in yam export agribusiness. Policies on literacy improvement, participation in relevant cooperative societies, extension services, and tenure security that propels rural households to participate in yam agribusiness should be put in place in order to deal decisively with rural poverty, enhance income and improve the wellbeing of Nigerians.

\section{REFERENCES}

ACHANDI, E. L., \& MUJAWAMARIYA, G. (2016). Market participation by smallholder rice farmers in Tanzania: a double hurdle analysis. Studies in Agricultural Economics 118, 112-115 http://dx.doi.org/10.7896/j.1528

AIGHEWI, B. A., MAROYA, N. G., \& ASIEDU, R. (2014). Seed Yam production from minisetts; a training manual. Ibadan. International Institute for Tropical Agriculture (IITA). p. 43. https://hdl.handle.net/10568/81044

ANDERSON, D., SWEENY, J., WILLIAMS, T., FREEMAN, J., \& SHOESMITH, E. (2007). Statistics for business and economics. Thomons Learning.

AGRICULTURAL TRANSFORMATION AGENDA [ATA] (2014). Mid-Term report of the transformation agenda (May 2011 - May 2013). Taking Stock, Moving $\quad$ Forward. 256p. https://nigerianstat.gov.ng/pdfuploads/MIDTERM\%20REPORT\%20OF\%20THE\%20TRANSF ORMATION\%20AGENDA\%20.pdf

BARRETT C. B. (2008). Smallholder market participation: concepts and evidence from Eastern and Southern Africa. Food Policy, 33, 229-317. https://citeseerx.ist.psu.edu/viewdoc/download?doi=1 $\underline{0.1 .1 .462 .1106 \& \mathrm{rep}=\mathrm{rep} 1 \& \mathrm{type}=\mathrm{pdf}}$

BERGH, K., OROZCO, P., GEGERTY, M. K., \& ANDERSON, C. L. (2012). Yam value chain: Nigeria, EPAR Brief No. 207, Evans School of Public Affairs, University of Washington, Evans School Policy Analysis and Research (EPAR) https://doi.org/10.21955/gatesopenres.11155 $\underline{42.1}$

BOBOJONOV, I., TEUBER, R., HASANOV, S., URUTYAN, V., \& GLAUBEN, T. (2016). Farmers' export market participation decisions in transition economies: a comparative study between Armenia and Uzbekistan. Development Studies Research, 3(1), 25 35. https://doi.org/10.1080/21665095.2016.1262272

ENETE, A. A., \& IGBOKWE, E. M. (2009). Cassava market participation decisions of producing households in Africa. Tropicultura, 27(3), 129 - 136. http://www.tropicultura.org/text/v27n3/129.pdf

ENETE, A. A., OTITOJU, M. A., \& IHEMEZIE, E. J. (2015). The choice of climate change adaptation strategies among food crop farmers in Southwest Nigeria, Nigerian Journal of Agricultural Economics, 5(1), 72-80. 10.22004/ag.econ.267812

FAOSTAT (2019). Food and Agriculture Organization of the United Nations, 2019. Production: crops. Available at: http://faostat.fao.org/

GEOFFREY, S. K., HILLARY, B. K., LAWRENCE, K. K., \& MARY. M. C. (2013). Determinants of market participation among small-scale pineapple farmers in Kericho County. Kenya Journal of Economics and Sustainable Development, 4, 59-66.

GUJARATI, D. N., PORTER, D. C., \& GUNASEKAR, S. (2012). Basic Econometrics (5 ${ }^{\text {th }}$ Edition). New Delhi: Tata McGraw Hill Education Private Limited.

KEY, N., \& RUNSTEN, D. (1999). Contract farming, smallholders and rural development in Latin America: 
the organization of agroprocessing firms and the scale of outgrower production. World Development, 27(2), $381-401$. $\underline{750 X(98) 00144-2}$ https://doi.org/10.1016/S0305-

KYAW, N. N., AHN, S., \& LEE, S. H. (2018). Analysis of the factors influencing market participation among smallholder rice farmers in Magway Region, Central Dry Zone of Myanmar. Sustainability, 10(12), 4441. https://doi.org/10.3390/su10124441

MARKELOVA, H., MEINZEN-DICK, R. HELLIN, J., \& DOHRN, S. (2009). Collective action for smallholder market access. Food Policy, 34(1),1-7. https://doi.org/10.1016/j.foodpol.2008.10.001

MATUNGUL, P. M., LYNE, M. C., \& ORTMANN, G. F., (2001). Transaction costs and crop marketing in the communal areas of Impendle and Swayimana, KwaZulu Natal. Development Southern Africa, 18(3), 347-363. https://doi.org/10.1080/03768350120070017

MURIITHI, B. W., \& MATZ, J. A. (2014). Smallholder participation in the commercialization of vegetables: evidence from Kenyan panel data. Quarterly Journal of International Agriculture, 53(2), 141168. $\underline{10.22004 / a g . e c o n .195733}$

NATIONAL BUREAU FOR STATISTICS (NBS) (2007). Agricultural Survey Report November, 2007. Abuja: Federal Government of Nigeria, 143pp.

OPARINDE, L. O., \& DARAMOLA, A. G. (2014). Determinants of market participation by maize farmers in Ondo State, Nigeria. Journal of Economics and Sustainable Development, 5(1), 69-77.

OSMANI, A. G., \& HOSSAIN, E. (2015). Market participation decision of smallholder farmers and its determinants in Bangladesh. Economics of $\begin{array}{lllll}\text { Agriculture, } & 62(1), & 163 & - & 179 .\end{array}$ https://doi.org/10.5937/ekoPolj1501163G

OTITOJU, M. A. (2013). The effects of climate change adaptation strategies on food crop production efficiency in Southwestern Nigeria. PhD thesis, Department of Agricultural Economics, University of Nigeria, Nsukka. Nigeria.
PINGALI, P., STAMOULIS, K., \& STRINGER R (2006). Eradicating extreme poverty and hunger: towards coherent policy agenda. Food agric. Org (FAO), Rome. ESA Working Paper No. 06-01. http://www.fao.org/3/af839t/af839t.pdf

POULTON, C., DORWARD, A., \& KYDD, J., (2010). The future of small farms: new directions for services, institutions, and intermediation. World Development, 38(10), 1413-1428. https://doi.org/10.1016/j.worlddev.2009.06.009

RANDELA, R., ALEMU, Z. G., \& GROENEWALD, J. A. (2008). Factors enhancing market participation by small-scale cotton farmers, Agrekon, 47(4), 451- 469. https://doi.org/10.1080/03031853.2008.9523810

ROHRBACH, D. D., BISHAW, Z., \& VAN GASTEL, A. J. G. (eds) (1990). Alternative strategies for smallholder seed supply. Proceedings of an international conference on options for strengthening national and regional seed systems in Africa and West Asia, 10-14 Mar 1997, Harare,Zimbabwe. Patancheru 502 324, Andhra Pradesh, India: ICRISAT. 288 pp.

SCHIPMANN, C., \& QAIM, M. (2011). Supply Chain Differentiation, Contract Agriculture, and Farmers' Marketing Preferences: The Case of Sweet Pepper in Thailand. Food Policy, 36, 667-677. https://doi.org/10.1016/j.foodpol.2011.07.004

SIZIBA, S., NYIKAHADZOI, K., DIAGNE, A., FATUNBI, A. O., \& ADEKUNLE, A. A. (2011). Determinants of cereal market participation by SubSaharan Africa smallholder farmer. Learning Public Journal of Agriculture and Environment Studies, 2(1), 180-193.

VERTER, N., \& BEČVÁŘOVÁ, V. (2015). An analysis of yam production in Nigeria. Acta Universitatis Agriculturae et Silviculturae Mendelianae Brunensis, 63(2), 659-665. http://dx.doi.org/10.11118/actaun201563020659 